\title{
Hydrogels Formed by Multiple Peptide Ligation Reactions to Fasten Corneal Transplants
}

\author{
Michel Wathier, C. Starck Johnson, ${ }^{\dagger}$ Terry Kim, ${ }^{\dagger}$ and Mark W. Grinstaff* \\ Departments of Biomedical Engineering and Chemistry, Metcalf Center for Science and \\ Engineering, Boston University, Boston, MA 02215, USA. ${ }^{\dagger}$ Department of \\ Ophthalmology, Duke University Medical Center, Durham NC 27710.
}

\section{Experimental section}

Material. All solvents were dried and freshly distilled prior to use $\left(\mathrm{CH}_{2} \mathrm{Cl}_{2}\right.$ with $\mathrm{CaH}_{2}$ and $\mathrm{MeOH}$ with $\mathrm{Na}$ ) or were purchased from Acros (DMF). All chemicals were purchased from Aldrich, Acros as highest purity grade and used without further purification. All reactions were performed under nitrogen atmosphere. NMR spectra were recorded on a Varian INOVA spectrometer (for ${ }^{1} \mathrm{H}$ and ${ }^{13} \mathrm{C}$ at 400 and $100.6 \mathrm{MHz}$, respectively). Elemental analysis was obtained from Atlantic Microlab, Inc. A TA Instruments RA 1000 was used for the rheological measurements. DCM = dichloromethane, $\mathrm{DMF}=N, N$-dimethylformamide, $\mathrm{TFA}=$ trifluoroaceticacid, $\mathrm{PEG}=$ polyethylene glycol, $\mathrm{Py}=$ pyridine. The buffer $\mathrm{pH}=7.4$ was prepared from HEPES $(100$ $\mathrm{mM}$ ) with $\mathrm{NaOH} 1 \mathrm{M}$.

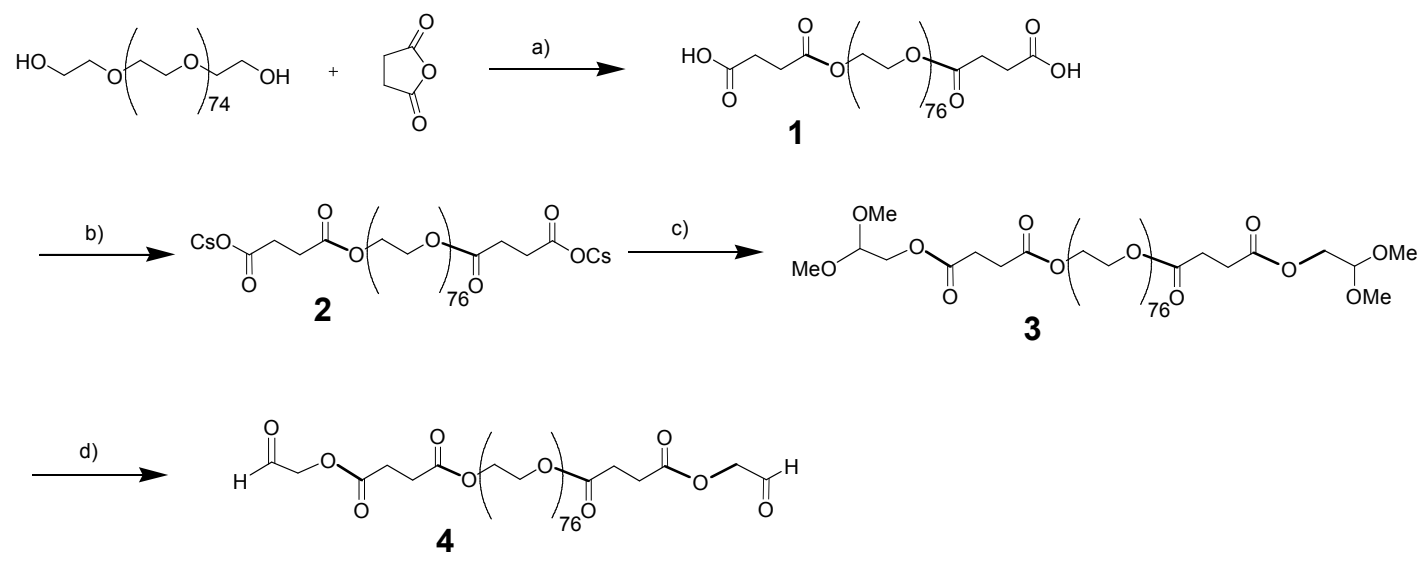

a) Py, 2 days, $25^{\circ} \mathrm{C}, 95 \%$, b) $\mathrm{CsCO}_{3} 1 \mathrm{M}, 99 \%$, c) DMF, bromoacetaldehyde dimethyl acetal, 2 days, $80{ }^{\circ} \mathrm{C}, 90 \%$, d) $\mathrm{DCM} / \mathrm{TFA}(90 / 10), 2 \mathrm{~h}, 25{ }^{\circ} \mathrm{C}, 90 \%$.

Figure 1. Synthesis of the polyethylene glycol diester-aldehyde.

\section{Synthesis of Bis-succinic acid-poly(ethylene glycol), 1}

Polyethylene glycol Mw=3400 g/mol (10 g, $3 \mathrm{mmol})$ was dissolved in pyridine $(50 \mathrm{~mL})$. After 5 minutes, the succinic anhydride $(1.17 \mathrm{~g}, 12 \mathrm{mmol})$ was added at $0{ }^{\circ} \mathrm{C}$. The 
reaction mixture was stirred for $24 \mathrm{~h}$ at $25{ }^{\circ} \mathrm{C}$ under $\mathrm{N}_{2}$. After concentration under vacuum the mixture was dissolved in DCM and purified by precipitation in cool ether to afford a white powder $10 \mathrm{~g}(95 \%) .{ }^{1} \mathrm{H}$ NMR $\left(\mathrm{CDCl}_{3}\right)$ : $\delta 2.61$ (m, 8, $\left.\mathrm{CH}_{2}-\mathrm{CO}\right) ; 3.45-3.80$ (m, 340, PEG); $4.22\left(\mathrm{~m}, 4, \mathrm{CH}_{2} \mathrm{O}\right) \cdot{ }^{13} \mathrm{C}$ NMR $\left(\mathrm{CDCl}_{3}\right): \delta 29.13$ and $29.60\left(\mathrm{CH}_{2} \mathrm{CO}\right)$; $64.02\left(\mathrm{CH}_{2} \mathrm{O}\right)$; 69.18-70.75 (PEG), $172.73(\mathrm{CO}), 182.43\left(\mathrm{CO}_{2} \mathrm{H}\right)$. MALDI MS: $3652 \mathrm{~m} / \mathrm{z}$ $\left(\mathrm{M}^{+}\right)$(theory: $3600 \mathrm{~m} / z\left(\mathrm{M}^{+}\right)$).

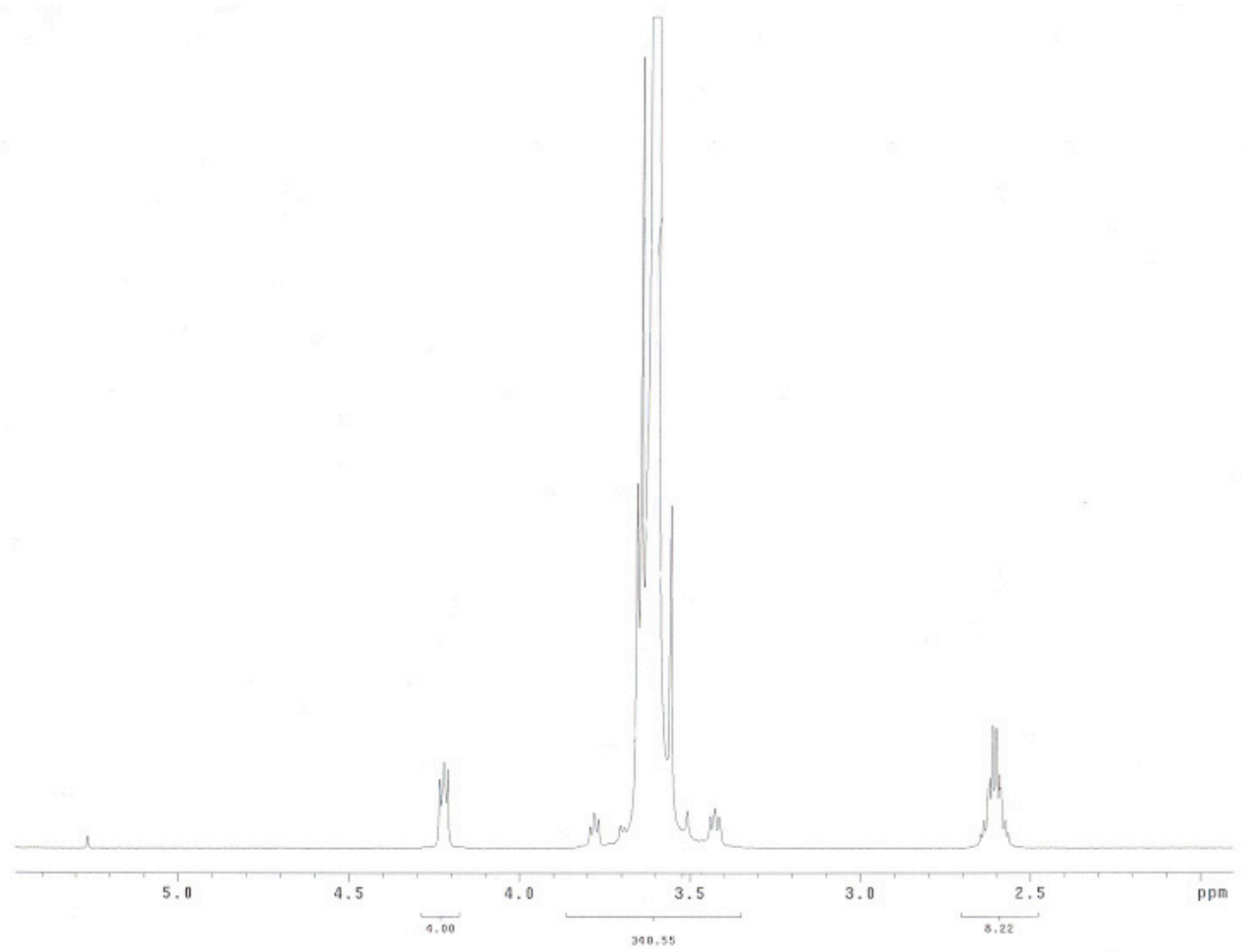

Figure 2. NMR spectrum of compound $\mathbf{1}$.

\section{Synthesis of Bis-succinic cesium salt-poly(ethylene glycol), 2}

The Cs salt of the compound was prepared to increase the nucleophilicity of the acid for the subsequent reaction. $\mathrm{CsCO}_{3} 1 \mathrm{M}$ was added to a solution of bis-succinic acidpoly(ethylene glycol) $(10 \mathrm{~g}, 3 \mathrm{mmol})$ in water $(100 \mathrm{~mL})$ until $\mathrm{pH}=8$. The sample was freeze-dried to give $10.8 \mathrm{~g}$ of the white compound $(99 \%) .{ }^{1} \mathrm{H}$ NMR $\left(\mathrm{CDCl}_{3}\right): \delta 2.53(\mathrm{~m}$, 8, $\left.\mathrm{CH}_{2}-\mathrm{CO}\right) ; 3.42-3.80$ (m, 340, PEG); 4.25 (m, 4, $\left.\mathrm{CH}_{2} \mathrm{O}\right) .{ }^{13} \mathrm{C}$ NMR $\left(\mathrm{CDCl}_{3}\right): \delta 29.70$ and $31.21\left(\mathrm{CH}_{2} \mathrm{CO}\right) ; 63.16\left(\mathrm{CH}_{2} \mathrm{O}\right)$; 70.19-70.35 (PEG); 173.14 and $174.82(\mathrm{CO})$. MALDI MS: $3901 \mathrm{~m} / z\left(\mathrm{M}^{+}\right)$(theory: $3866 \mathrm{~m} / z\left(\mathrm{M}^{+}\right)$). 


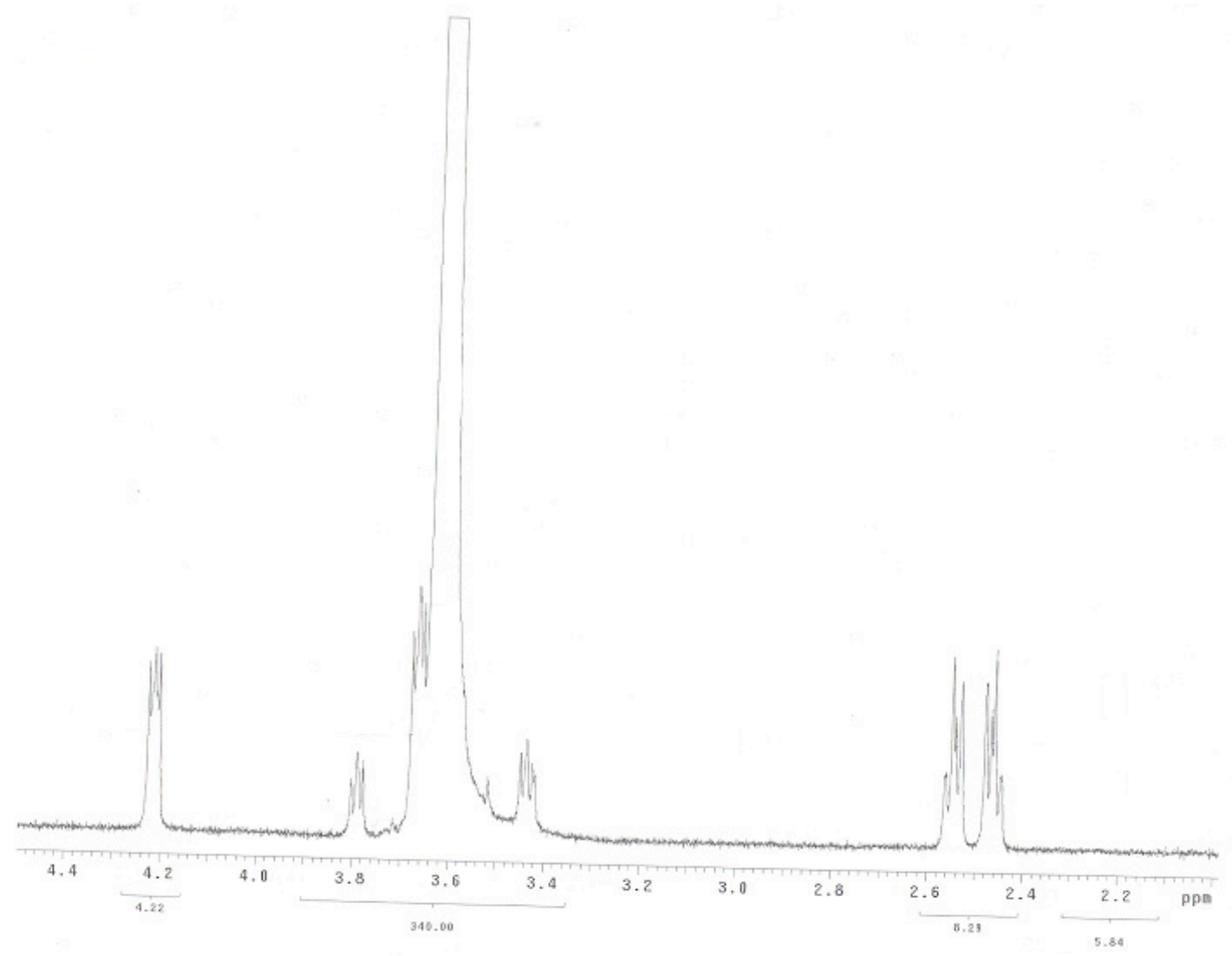

Figure 3. NMR spectrum of compound 2.

\section{Synthesis of Bis-2,2-dimethoxyethyl succinate-poly(ethylene glycol), 3}

Bis-succinic cesium salt-poly(ethylene glycol) (3 g, $0.7 \mathrm{mmol})$ was dissolved in DMF (40 $\mathrm{mL})$. After $5 \mathrm{~min}$ the 2-bromo-1,1-dimethoxyethane $(520 \mathrm{mg}, 3 \mathrm{mmol})$ was added at 80 ${ }^{\circ} \mathrm{C}$ and the reaction mixture was stirred for $24 \mathrm{~h}$ under $\mathrm{N}_{2}$. After concentration under vacuum the mixture was dissolved in DCM $(200 \mathrm{~mL})$ and washed with $\mathrm{NaHCO}_{3}(2 \times 100$ $\mathrm{mL})$, water $(2 \times 100 \mathrm{~mL})$, and then dried over $\mathrm{Na}_{2} \mathrm{SO}_{4}$. Evaporation of the organic solvent gave an oil that was purified by precipitation in cool ether to give a white powder $2.62 \mathrm{~g}$ (90 \%). ${ }^{1} \mathrm{H} \mathrm{NMR}\left(\mathrm{CDCl}_{3}\right): \delta 2.64$ (s, 8, $\left.\mathrm{CH}_{2}-\mathrm{CO}\right) ; 3.36$ (s, 12, $\left.\mathrm{CH}_{3}\right) ; 3.44-3.79$ (m, 340, PEG); 4.10 (d, 4, $\left.\mathrm{CH}_{2}\right) ; 4.21\left(\mathrm{~m}, 4, \mathrm{CH}_{2} \mathrm{OCO}\right) ; 4.53$ (t, 2, $\left.\mathrm{CH}\right) .{ }^{13} \mathrm{C} \mathrm{NMR}\left(\mathrm{CDCl}_{3}\right): \delta$ $29.18\left(\mathrm{CH}_{2} \mathrm{CO}\right) ; 54.15\left(\mathrm{CH}_{3}\right) ; 63.36\left(\mathrm{CH}_{2} \mathrm{O}\right) ; 64.12\left(\mathrm{CH}_{2} \mathrm{CH}\right) ; 69.27-70.78(P E G)$; $105.25(\mathrm{CH}) ; 173.09$ and $173.12(\mathrm{CO})$. MALDI MS: $3787 \mathrm{~m} / \mathrm{z}\left(\mathrm{M}^{+}\right)$(theory: $3772 \mathrm{~m} / \mathrm{z}$ $\left.\left(\mathrm{M}^{+}\right)\right)$. 


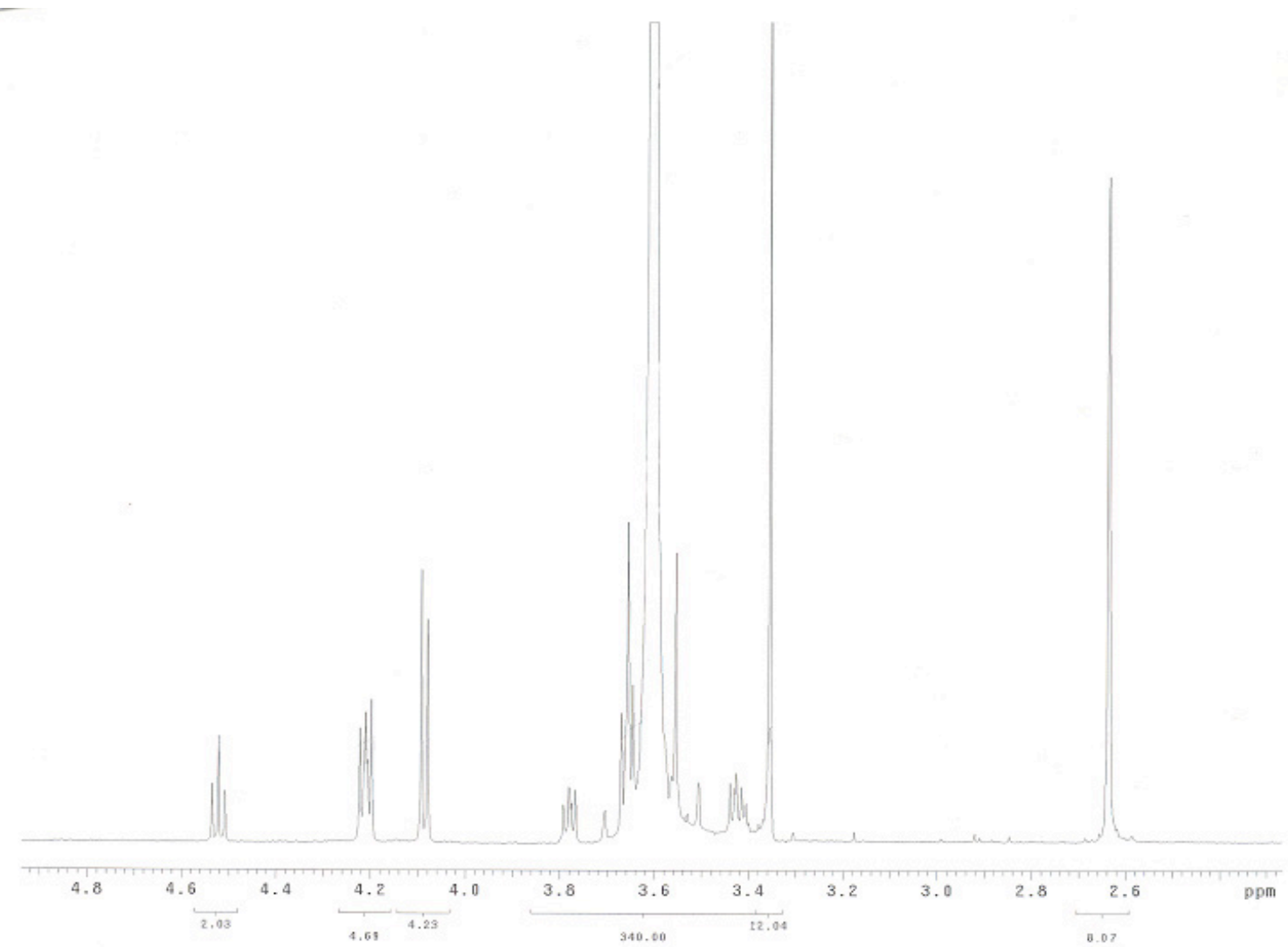

Figure 4. NMR spectrum of compound 3.

\section{Synthesis of Bis-2-oxoethyl succinate-poly(ethylene glycol), 4}

TFA (2.5 mL) was added in 10 portions over 10 minutes to a solution of bis-2,2dimethoxyethyl succinate-poly(ethylene glycol) (1 g, $0.26 \mathrm{mmol})$ in freshly distilled $\mathrm{CH}_{2} \mathrm{Cl}_{2}(25 \mathrm{~mL})$ at $0{ }^{\circ} \mathrm{C}$. The reaction mixture was stirred under $\mathrm{N}_{2}$ at $25{ }^{\circ} \mathrm{C}$ for $2 \mathrm{~h}$. The product was isolated after evaporation of the solvent and precipitation in cool ether to give a pure white compound $877 \mathrm{mg}(90 \%) .{ }^{1} \mathrm{H}$ NMR $\left(\mathrm{CDCl}_{3}\right): \delta 2.71\left(\mathrm{~m}, 8, \mathrm{CH}_{2} \mathrm{CO}\right)$; 3.44-3.81 (m, 340, PEG); 4.24 (m, 4, $\mathrm{CH}_{2} \mathrm{OCO}$ ); 4.67 (s, 4, $\mathrm{CH}_{2} \mathrm{CHO}$ ); 9.58 (s, 2, CHO). ${ }^{13} \mathrm{C}$ NMR $\left(\mathrm{CDCl}_{3}\right): \delta 29.72\left(\mathrm{CH}_{2} \mathrm{CO}\right) ; 69.20\left(\mathrm{CH}_{2} \mathrm{CHO}\right) ; 69.40-70.74(\mathrm{PEG}) ; 173.20$ (CO); $169.27(\mathrm{CO}), 196.12(\mathrm{CHO})$. MALDI MS: $3694\left(\mathrm{M}^{+}\right)$(theory: $3680\left(\mathrm{M}^{+}\right)$). 


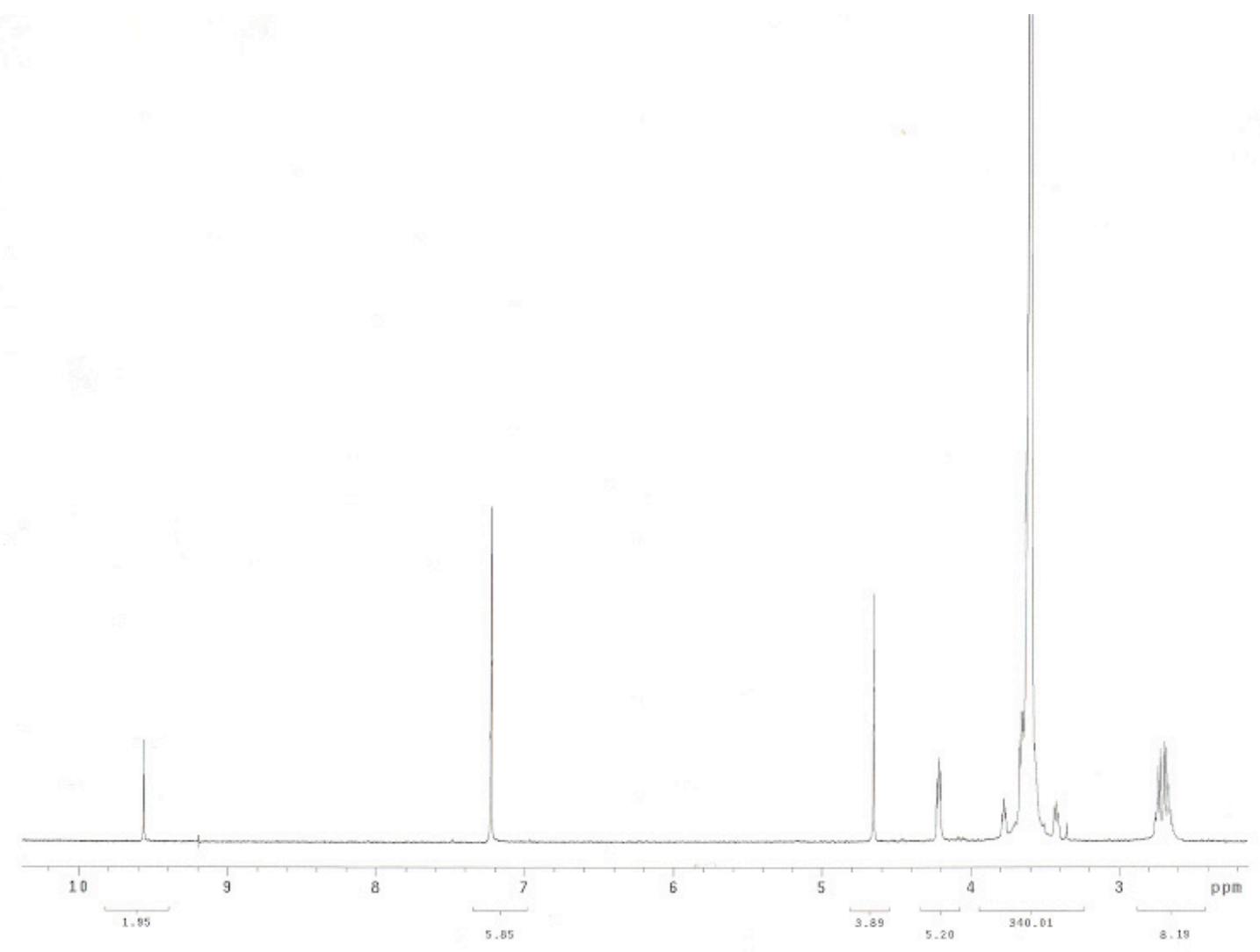

Figure 5. NMR spectrum of compound 4.

The $N$-terminated cysteine lysine-based dendron was prepared accordingly to Wathier, M.; Jung, P. J.; Carnahan, M. A.; Kim, T.; Grinstaff, M. W., J. Am. Chem. Soc. 2004, 126, 12744-12745, and characterized by NMR and elemental analysis.

\section{Synthesis of the model compound}
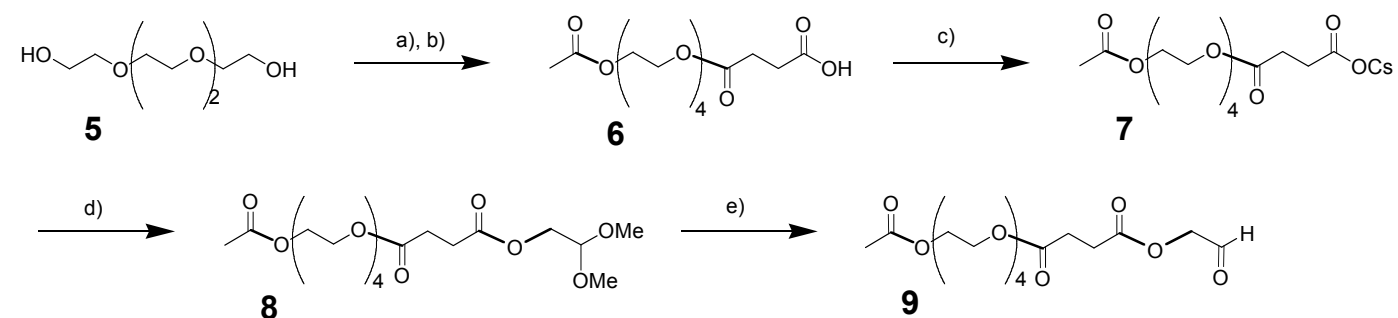

a) Acitic anhydride, Py, 1 day, $25^{\circ} \mathrm{C}, 35 \%$, b) Succinic anhydride, Py, 2 days, $25^{\circ} \mathrm{C}, 92 \%$, b) $\mathrm{CsCO}_{3} 1 \mathrm{M}, 99 \%$, c) DMF, bromoacetaldehyde dimethyl acetal, 2 days, $80^{\circ} \mathrm{C}, 98 \%$, d) DCM/TFA $(90 / 10), 2 \mathrm{~h}, 25^{\circ} \mathrm{C}, 99 \%$.

Figure 6. Synthesis of the tetraethylene glycol diester-aldehyde. 


\section{Acetic acid 2-\{2-[2-(2-hydroxy-ethoxy)-ethoxy]-ethoxy\}-ethyl ester, 5}

Tetraethylene glycol (25 g, $129 \mathrm{mmol})$ was dissolved in pyridine $(100 \mathrm{~mL})$. After $5 \mathrm{~min}$ the acetic anhydride $(13.1 \mathrm{~g}, 129 \mathrm{mmol})$ was added at $0{ }^{\circ} \mathrm{C}$. The reaction mixture was stirred for $24 \mathrm{~h}$ at $25{ }^{\circ} \mathrm{C}$ under $\mathrm{N}_{2}$. The reaction mixture was poured in water $(200 \mathrm{~mL})$ then extrated with DCM $(3 * 100 \mathrm{~mL})$. The organic layers were washed with $\mathrm{HCl} 1 \mathrm{M}(100$ $\mathrm{ml})$, brine $(100 \mathrm{~mL})$, and dry over sodium sulfate. After concentration under vacuum the compound was purified by silica gel column with $\mathrm{DCM} / \mathrm{MeOH}(95 / 5)$ to give an colorless oil $10.6 \mathrm{~g} \mathrm{(35 \% ).}{ }^{1} \mathrm{H}$ NMR $\left(\mathrm{CDCl}_{3}\right)$ : $\delta 2.00$ (s, 3, $\left.\mathrm{CH}_{3}\right) ; 2.83$ (bt, 1, $\left.\mathrm{OH}\right) ; 3.51$ $3.65\left(\mathrm{~m}, 14, \mathrm{CH}_{2} \mathrm{O}\right), 4.15\left(\mathrm{~m}, 2, \mathrm{CH}_{2} \mathrm{OCO}\right) .{ }^{13} \mathrm{C} \mathrm{NMR}\left(\mathrm{CDCl}_{3}\right): \delta 29.42\left(\mathrm{CH}_{3}\right) ; 62.19$ $\left(\mathrm{CH}_{2} \mathrm{OH}\right) ; 64.15\left(\mathrm{CH}_{2} \mathrm{OCOCH}_{3}\right) ; 69.98-71.56\left(\mathrm{CH}_{2}-\mathrm{O}\right) . \quad \mathrm{FAB}^{+} \mathrm{MS}: 237 \mathrm{~m} / z\left(\mathrm{MH}^{+}\right)$ (theory: $236 \mathrm{~m} / z\left(\mathrm{M}^{+}\right)$).

\section{Succinic acid mono-(2-\{2-[2-(2-acetoxy-ethoxy)-ethoxy]-ethoxy\}-ethyl) ester, 6}

Acetic acid 2-\{2-[2-(2-hydroxy-ethoxy)-ethoxy]-ethoxy\}-ethyl ester (10 g, $4.2 \mathrm{mmol})$ was dissolved in pyridine $(50 \mathrm{~mL})$. After $5 \mathrm{~min}$ the succinic anhydride $(840 \mathrm{mg}, 8.4$ mmol) was added at $0{ }^{\circ} \mathrm{C}$. The reaction mixture was stirred for $24 \mathrm{~h}$ at $25{ }^{\circ} \mathrm{C}$ under $\mathrm{N}_{2}$. After concentration under vacuum the mixture was dissolved in $\mathrm{NaHCO}_{3} 10 \%(100 \mathrm{~mL})$ then extracted with DCM $(3 * 100 \mathrm{~mL})$. The organic layers was acidified with $\mathrm{HCl} 1 \mathrm{M}$, dry over sodium sulfate and concentrated under vacuum to afford a colorless oil $12.47 \mathrm{~g}$ (92 \%). ${ }^{1} \mathrm{H}$ NMR $\left(\mathrm{CDCl}_{3}\right): \delta 1.99$ (s, 3, $\left.\mathrm{CH}_{3}\right) ; 2.57$ (s, 4, $\left.\mathrm{CH}_{2}-\mathrm{CO}\right)$; 3.56-3.62 (m, 12, $\left.\mathrm{CH}_{2} \mathrm{CH}_{2} \mathrm{OCO}\right), 4.12-4.18\left(\mathrm{~m}, 4, \mathrm{CH}_{2} \mathrm{OCO}\right) .{ }^{13} \mathrm{C} \mathrm{NMR}\left(\mathrm{CDCl}_{3}\right): \delta 29.44\left(\mathrm{CH}_{3}\right) ; 64.11$ and $64.39\left(\mathrm{CH}_{2}-\mathrm{OCO}\right) ; 69.53$ and $69.61\left(\mathrm{CH}_{2} \mathrm{CO}\right) ; 71.00-71.17\left(\mathrm{CH}_{2}-\mathrm{O}\right) ; 171.77$ and 172.69 $(\mathrm{CO}) ; 177.11\left(\mathrm{CO}_{2} \mathrm{H}\right)$. $\mathrm{FAB}^{+} \mathrm{MS}: 337 \mathrm{~m} / z\left(\mathrm{MH}^{+}\right)$(theory: $336 \mathrm{~m} / z\left(\mathrm{M}^{+}\right)$).

\section{Succinic cesium salt mono-(2-\{2-[2-(2-acetoxy-ethoxy)-ethoxy]-ethoxy\}-ethyl) ester, 7}

$\mathrm{CsCO}_{3} 1 \mathrm{M}$ was added to a solution of succinic acid mono-(2-\{2-[2-(2-acetoxy-ethoxy)ethoxy]-ethoxy -ethyl $)$ ester $(10 \mathrm{~g}, 21 \mathrm{mmol})$ in water $(100 \mathrm{~mL})$ until $\mathrm{pH}=8$. The flask was freezed dry to give $13.8 \mathrm{~g}$ of the white compound (99\%). The compound was used without characterization. 
Succinic acid 2-\{2-[2-(2-acetoxy-ethoxy)-ethoxy]-ethoxy\}-ethyl ester 2,2-dimethoxyethyl ester, 8

Succinic cesium salt mono-(2-\{2-[2-(2-acetoxy-ethoxy)-ethoxy]-ethoxy\}-ethyl) ester (1 g, $2.1 \mathrm{mmol})$ was dissolved in DMF $(40 \mathrm{~mL})$. After $5 \mathrm{~min}$, the 2-bromo-1,1dimethoxyethane $(540 \mathrm{mg}, 3.2 \mathrm{mmol})$ was added at $65^{\circ} \mathrm{C}$. The reaction mixture was stirred for $24 \mathrm{~h}$ at $65{ }^{\circ} \mathrm{C}$ under $\mathrm{N}_{2}$. After concentration under vacuum the mixture was dissolved in DCM $(200 \mathrm{~mL})$ and washed with $\mathrm{NaHCO}_{3}(2 \times 100 \mathrm{~mL})$, water $(2 \times 100 \mathrm{~mL})$, and then dried over $\mathrm{Na}_{2} \mathrm{SO}_{4}$. Evaporation of the organic solvent gave an oil that was purified by silica gel column in DCM/MeOH (95/5) to lead a colorless oil $0.887 \mathrm{~g}(98$ \%). ${ }^{1} \mathrm{H} \mathrm{NMR}\left(\mathrm{CDCl}_{3}\right): \delta 2.08\left(\mathrm{~s}, 3, \mathrm{CH}_{3}\right) ; 2.67$ (s, 4, $\left.\mathrm{CH}_{2}-\mathrm{CO}\right) ; 3.39$ (s, 6, $\left.\mathrm{CH}_{3}\right) ; 3.65-$ 3.67 (m, 8, $\left.\mathrm{CH}_{2}-\mathrm{O}\right) ; 3.70$ (m, 4, $\left.\mathrm{CH}_{2} \mathrm{CH}_{2} \mathrm{OCO}\right) ; 4.12$ (d, 2, $\mathrm{CH}_{2} \mathrm{CH}$ ), 4.21-4.26 (m, 4, $\left.\mathrm{CH}_{2} \mathrm{OCO}\right), 4.56(\mathrm{t}, 1, \mathrm{CH}) .{ }^{13} \mathrm{C} \mathrm{NMR}\left(\mathrm{CDCl}_{3}\right): \delta 29.40\left(\mathrm{CH}_{3}\right) ; 54.42\left(\mathrm{OCH}_{3}\right) ; 63.64-$ $64.38\left(\mathrm{CH}_{2}-\mathrm{OCO}\right.$ and $\left.\mathrm{CH}_{2} \mathrm{CH}\right) ; 69.56\left(\mathrm{CH}_{2} \mathrm{CO}\right) ; 71.08-71.11\left(\mathrm{CH}_{2}-\mathrm{O}\right) ; 101.63(\mathrm{CH})$; 171.57, 172.44, and $172.69(\mathrm{CO}) . \mathrm{FAB}^{+} \mathrm{MS}: 225 \mathrm{~m} / z\left(\mathrm{MH}^{+}\right)$(theory: $\left.424 \mathrm{~m} / z\left(\mathrm{M}^{+}\right)\right)$.

\section{Succinic acid 2-\{2-[2-(2-acetoxy-ethoxy)-ethoxy]-ethoxy\}-ethyl ester 2-oxo-ethyl ester), 9}

TFA (3 mL) was added in 10 portions over 10 minutes to a solution of succinic acid 2$\{2-[2-(2-a c e t o x y-e t h o x y)$-ethoxy]-ethoxy $\}$-ethyl ester 2,2-dimethoxy-ethyl ester (0.8 g, $1.88 \mathrm{mmol})$ in freshly distilled $\mathrm{CH}_{2} \mathrm{Cl}_{2}(20 \mathrm{~mL})$ at $0{ }^{\circ} \mathrm{C}$. The reaction mixture was stirred under $\mathrm{N}_{2}$ at $25^{\circ} \mathrm{C}$ for $3 \mathrm{~h}$. The product was isolated after evaporation of the solvent to give a pure white compound $700 \mathrm{mg}(99 \%) .{ }^{1} \mathrm{H} \mathrm{NMR}\left(\mathrm{CDCl}_{3}\right): \delta 2.11$ (s, 3, $\left.\mathrm{CH}_{3}\right)$; 2.722.79 (m, 4, $\mathrm{CH}_{2} \mathrm{CO}$ ); 3.72-3.77 (m, 12, $\mathrm{CH}_{2} \mathrm{O}$ and $\left.\mathrm{CH}_{2} \mathrm{CH}_{2} \mathrm{OCO}\right) ; 4.27$ (m, 4, $\mathrm{CH}_{2} \mathrm{OCO}$ ); $4.72\left(\mathrm{~s}, 2, \mathrm{CH}_{2} \mathrm{CHO}\right), 9.60(\mathrm{~s}, 1, \mathrm{CHO}) .{ }^{3} \mathrm{C} \mathrm{NMR}\left(\mathrm{CDCl}_{3}\right): \delta 29.45\left(\mathrm{CH}_{3}\right) ; 64.16\left(\mathrm{CH}_{2}-\right.$ OCO); 69.40-71.12 ( $\mathrm{CH}_{2} \mathrm{CO}, \mathrm{CH}_{2}-\mathrm{O}$, and $\left.\mathrm{CH}_{2} \mathrm{CHO}\right) ; 171.82,172.33$, and 172.66 (CO, and $\mathrm{CHO})$. FAB ${ }^{+} \mathrm{MS}: 379\left(\mathrm{MH}^{+}\right)$(theory: $\left.378\left(\mathrm{M}^{+}\right)\right)$. 


\section{General sample procedure preparation:}

To prepare a sufficient amount of the crosslinked hydrogel to secure a corneal transplant, dendron (4.68 $\mathrm{mg}\left(1.92 \times 10^{-5} \mathrm{~mol}\right.$ of Cysteine) in $37.5 \mu \mathrm{L}$ of HEPES $\left.100 \mathrm{mM}, \mathrm{pH} 7.4\right)$ was mixed with polyethylene glycol diester-aldehyde $\left(32.8 \mathrm{mg}\left(1.92 \times 10^{-5} \mathrm{~mol}\right.\right.$ of aldehyde) in $37.5 \mu 1$ of HEPES $100 \mathrm{mM}, \mathrm{pH} 7.4$ ) to give $75 \mu \mathrm{L}$ of hydrogel adhesive. The ratio of cysteine to PEG functionality was $1: 1$, and the total concentration of polymer in solution was $33 \% \mathrm{wt}$. Upon mixing the two aqueous solutions, a network formed spontaneously within 30 seconds. When the ratio of cysteine to polyethylene glycol diester-aldehyde was changed from 1:1 to $1: 2$ or 2:1 the gelation time slowed and the crosslinked network was weaker. For example E decrease from $7 \times 10^{5} \mathrm{~Pa}$ to $4.6 \times 10^{5} \mathrm{~Pa}$ and $2.8 \times 10^{5} \mathrm{~Pa}$ for the $33 \%$ gel at the 1:1, 1:2 or 2:1 ratio, respectively (see Figure 7).

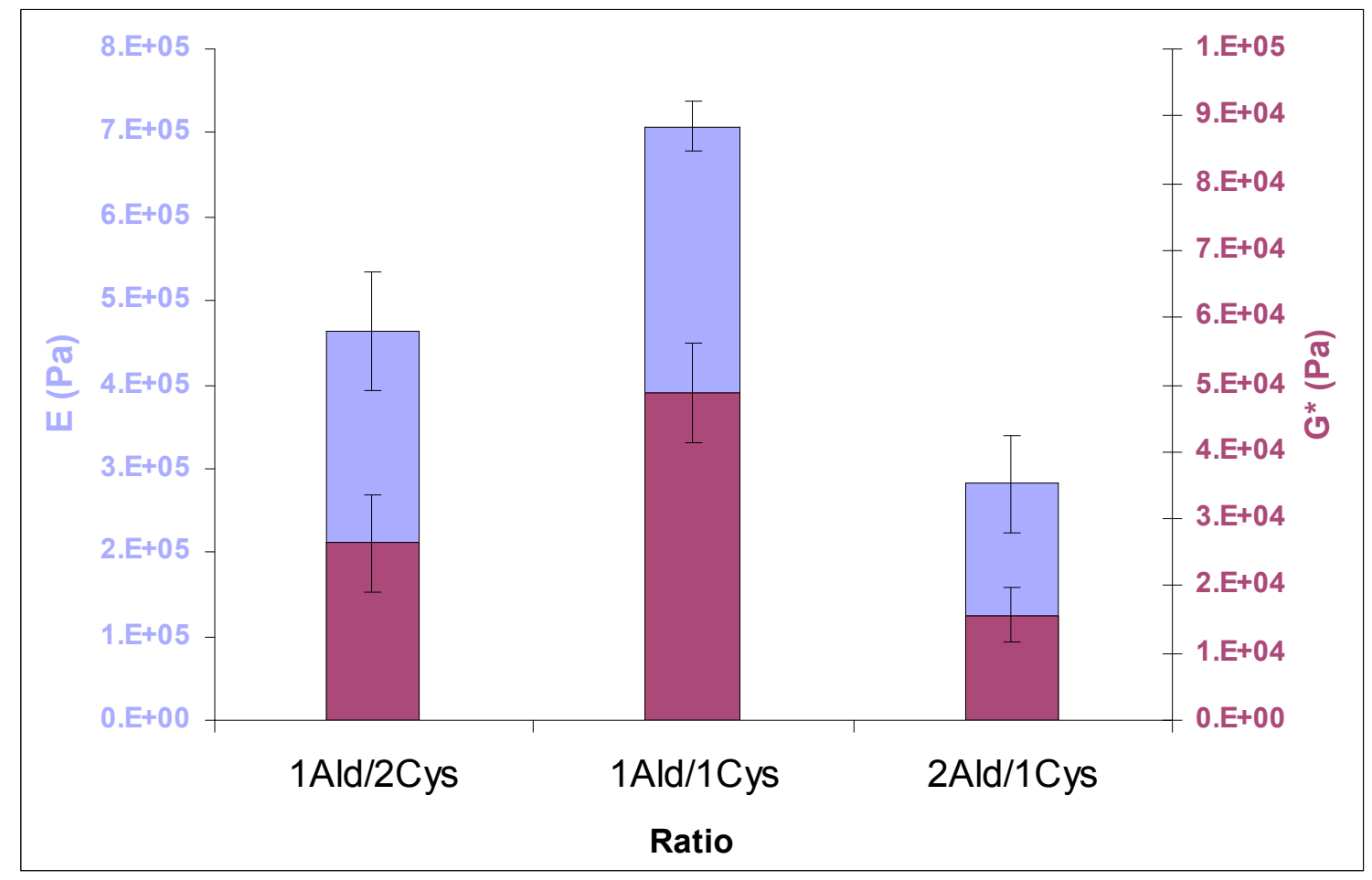

Figure 7. Compress modulus E (blue) and $\mathrm{G}^{*}$ (red) of $33 \mathrm{wt} \%$ gel with different ratios of aldehyde to cysteine reactive functionality.

\section{General procedure for rheological measurement:}

Cylindrical samples for dynamic mechanical testing were prepared by crosslinking biodendrimer solutions at three different $\%$ w/t by mixing the dendron $(75 \mu \mathrm{L})$ with the 
polyethylene glycol diester-aldehyde $(75 \mu \mathrm{L})$ in HEPES buffer at $\mathrm{pH}=7.4$. A cylindrical mold (dia. $=8 \mathrm{~mm}, \mathrm{~h}=3 \mathrm{~mm}$ ) was used to ensure inter-sample consistency and each preparation was made in triplicate. The crosslinked samples were removed from the molds and subsequently analyzed. The samples were investigated with a TA 1000 rheometer equipped with a peltier temperature control at 0.1 to $10 \mathrm{~Hz}$ (maximum strain amplitude of $0.5 \%$ ) with a parallel-plate geometry. Before the first measurement, the samples were placed at $25^{\circ} \mathrm{C}$ for 24 hours. This ensured that the crosslinking reaction was complete as mechanical measurements as a function of time show no change in $\mathrm{E}$ after 1 hour of formation. An $8 \mathrm{~mm}$ steel plate diameter geometry was used to measure the rheological properties. The choice of a small geometry less stress-sensitive plate was based on the amount of material available. Next the samples were placed in buffer for 48 hours at $25^{\circ} \mathrm{C}$. Swelling is complete after 24 hours as determined by following the mass increase of the hydrogel. After swelling, either $12 \mathrm{~mm}$ diameter steel plate or $20 \mathrm{~mm}$ aluminum plate geometry were used to measure the rheological properties of the hydrogel. Care was taken to use always a bigger geometry than sample. All rheological measurements were performed with a cover and at $25^{\circ} \mathrm{C}$ to avoid evaporation. The mechanical measurements were insensitive to temperature and this was confirmed at two different temperature $\left(25^{\circ} \mathrm{C}\right.$ and $\left.37^{\circ} \mathrm{C}\right)$ on one sample of each group. Each rheological measurement was performed at $25{ }^{\circ} \mathrm{C}$ as follow. First to determine the Pseudo-Linear Viscoelastic Region (LVR) an oscillatory strain sweep (strain amplitude from 0.01 to $10 \%)$ at fixed frequency $(1 \mathrm{~Hz})$ was perform. Secondly, a normal force (enough to obtain a flat surface) was applied to the gel using either geometry and a strain-rate compression test (maximum compression as $10 \%$ of the height) was realized to determine the compress modulus, E. After equilibrium (15 min at zero strain) an oscillatory frequency sweep (from 0.1 to $10 \mathrm{~Hz}$ ) with a controlled strain for a linear response (as determine in the LVR test) was performed at $25^{\circ} \mathrm{C}$. This measures the storage modulus $\mathrm{G}$ ', the lost

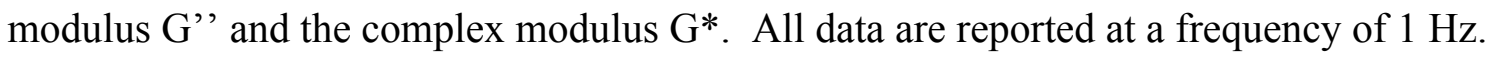
No significant frequency dependence was detected in the observed frequency range. The frequency independent complex shear modulus $\left|G^{*}\right|$, storage modulus G', loss modulus G", and the loss angle $\delta$ were determined. The dynamic mechanical properties (G', G", $\left|\mathrm{G}^{*}\right|$, and $\delta$ ) showed no appreciable frequency dependence from 0.1 to $10 \mathrm{~Hz}$. 


\section{NMR procedure for following the $\mathrm{O}, \mathrm{N}$ acyl migration in the model compounds}

The succinic acid 2-\{2-[2-(2-acetoxy-ethoxy)-ethoxy]-ethoxy $\}$-ethyl ester 2-oxo-ethyl ester), $9(30 \mathrm{mg}, 0.08 \mathrm{mmol})$ was disolved in $\mathrm{D}_{2} \mathrm{O}(300 \mu \mathrm{L})$. The resulting solution has acidic because of remaining TFA from the aldehyde deprotection step. The first spectrum acquired was of the starting material to asign the protons. Next, a second solution of cysteine methyl ester, $\mathrm{HCl}(13.7 \mathrm{mg}, 0.08 \mathrm{mmol})$ and dry $\mathrm{NaHCO}_{3}(6.7 \mathrm{mg}$, $0.08 \mathrm{mmol})$ was prepared in $\mathrm{D}_{2} \mathrm{O}(100 \mu \mathrm{L})$ and added to the previous solution. A second spectrum was acquired as soon as possible and noted as $\mathrm{t}=0$. Every $15 \mathrm{~min}$ a new spectrum was acquired and noted as $\mathrm{t}=15 \mathrm{~min}, \mathrm{t}=30 \mathrm{~min} .$. up to $3 \mathrm{~h}$ to obtain the fully thiazolidine formation (no more change observed on the integrations). After $3 \mathrm{~h}$, the $\mathrm{pH}$ was ajusted to 8 with dry $\mathrm{NaHCO}_{3}$ and a new spectrum was acquired as soon as possible and noted as $\mathrm{t}=0$. Again, every $15 \mathrm{~min}$ a new spectrum was acquired and noted as $\mathrm{t}=15$ $\min , 30 \min . .$. up to $3 \mathrm{~h}$ to obtain the fully $\mathrm{O}, \mathrm{N}$ acyl rearangment (no more change observed on the integrations).

With this model, we can follow the methylene protons alpha to the aldehyde and monitor the change in chemical shift as the reaction progress. For this study we controlled the $\mathrm{pH}$ from acid to block the $O, N$ acyl rearrangement and then changed the $\mathrm{pH}$ to basic to allow for the final step to occur. The first step of the reaction (before rearrangement) can be followed by the disappearance of the starting $\alpha$ methylene aldehyde at $4.05 \mathrm{ppm}$ and appearance of the $\alpha$ methylene ester at $3.88 \mathrm{ppm}$. By changing the $\mathrm{pH}$ of the solution to basic the $O, N$ acyl rearrangement occurs and the $\alpha$ methylene ester peak at $3.88 \mathrm{ppm}$ disappears and a new peak corresponding to the $\alpha$ methylene alcohol at $3.80 \mathrm{ppm}$ appears (see figure 8).

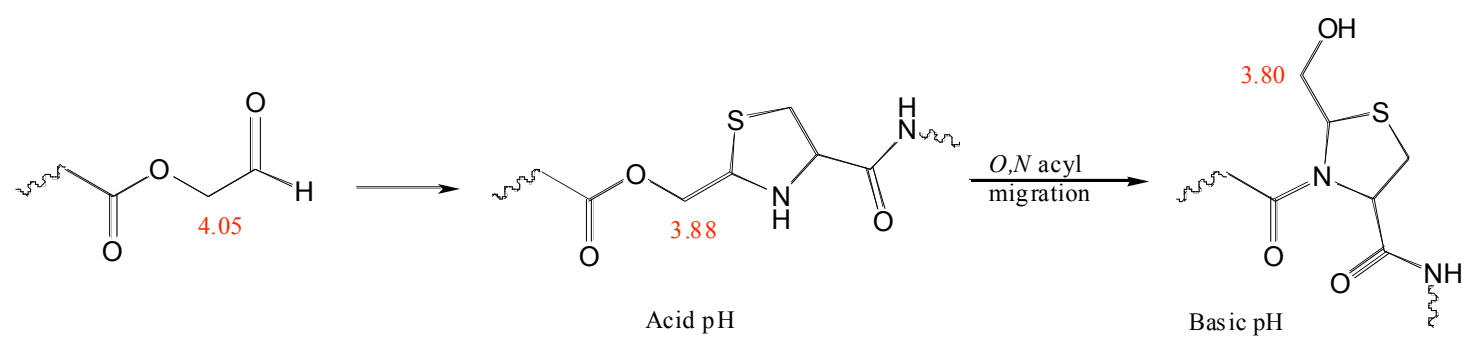

Figure 8. Sequential steps of the O,N acyl migration in the model compounds 


\section{PKP:}

Human donor eyes were obtained from the North Carolina Eye Bank. A fullthickness circumferential excision of the posterior sclera was made just anterior to the vortex veins using scissors. The vitreous, retina, uvea and lens were removed. The remaining corneal-scleral shell was mounted on a two-port artificial anterior chamber and secured in place. The chamber was constructed of rigid plastic and stainless steel by the Ophthalmic Biophysics Department at Duke University Eye Center. One port was attached via rigid tubing to a micro-infusion pump (KD Scientific, Model 100, Holliston, Massachusetts). The other port was attached via rigid tubing to a pressure monitor (Hewlett Packard, model CMS 24 Omnicare, Palo Alto, California). Air was flushed from the system and the transducer was zeroed with the system open to atmospheric pressure with the eye soft. The system was closed and the pressure remained at zero. The pressure was increased to $20 \mathrm{~mm} \mathrm{Hg}$ and an $8 \mathrm{~mm}$ central corneal trephination was made. This newly formed button was then autografted back to the original eye. The host-graft tissue interface was secured using sutures (16 or 8), sutures plus the hydrogel sealant, or the hydrogel alone. For the hydrogel sealant, $60 \mu \mathrm{L}$ of the sealant was applied to the wound to secure the autograft. Next, a balanced salt solution was infused into the chamber at a rate of $10 \mathrm{~mL} / \mathrm{hr}$. The eye was viewed under an operating microscope and as soon as a leak was visualized, the pressure was recorded (leaking pressure). Evidence of major wound leakage or wound dehiscence was used as endpoints for our leaking pressure studies. Figure 9 summarizes the result obtained during these experiments. The polymer solutions can be sterilized by filtration through $0.2 \mu \mathrm{m}$ filter (aseptic fill). This is one of the approved FDA methods for sterilization

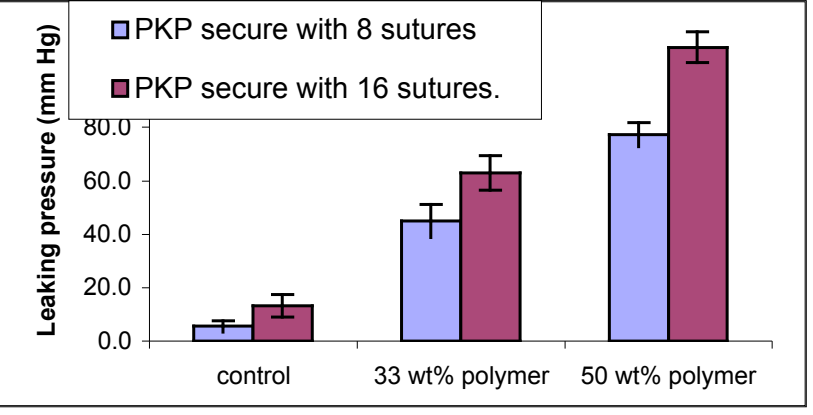

Figure 9. Leaking pressure for autographed eyes. 